\title{
Commensal Small Mammal Species and Bait Preferences in Urban Areas of Penang Island
}

\author{
Wan Nur Amni' ${ }^{1}$, Shakinah Ravindran ${ }^{1}$, Safwan Saufi ${ }^{1}$, Noor Hisham Hamid², Cik Mohd \\ Rizuan Zainal Abidin ${ }^{3}$, Abu Hassan Ahmad ${ }^{1}$ and Hasber Salim*1,4
}

\begin{abstract}
${ }^{1}$ School of Biological Sciences, Universiti Sains Malaysia, 11800 Penang, Malaysia. ${ }^{2}$ PPP Tun Razak, Felda Agricultural Services Sdn Bhd, 26400, Bandar Jengka, Pahang, Malaysia. ${ }^{3}$ Crop Protection Division, Felda Global Ventures (R\&D) Sdn Bhd, 27000, Jerantut, Pahang, Malaysia

${ }^{4}$ Vector Control and Research Unit, School of Biological Sciences, Universiti Sains Malaysia, 11800 Penang, Malaysia

*Corresponding author: hasbersalim@usm.my, amniesukri@gmail.com, shakinahravindran@gmail.com, mohdsafwan1989@gmail.com,nhisham.h@feldaglobal.com, rizuan.z@feldaglobal.com, aahassan@usm.my Received: $25^{\text {th }}$ Sep 2018 Accepted: $4^{\text {th }}$ Jul 2019

Published: $28^{\text {th }}$ Aug 2019
\end{abstract}

DOI: https://doi.org/10.22452/mjs.vol38no2.2

\begin{abstract}
Physical trapping is an important first step in controlling pest populations and species identification; and bait preferences are crucial information for effective management. This study was conducted to explore species diversity and bait preferences of commensal species in urban areas on Penang Island. Live trapping was carried out in eight sampling sites on Penang Island in commercial and residential areas. Eight different type of baits were used; apple and peanut butter (APB), white bread and peanut butter (BPB), salted fish (SF), salted fish and peanut butter (SFPB), white bread and fish extract (BFE), fried chicken leftover (FCL), vegetables and peanut butter (VPB) and sausages (S). The most successful bait was the high protein bait, fried chicken leftover (FCL), with a capture success rate of $35.56 \%$. We also analysed the bait preferences for the different species of small mammals captured in our study. Five species of small mammals were captured in our study sites: Rattus norvegicus, Rattus rattus, Mus musculus, Bandicota bengalensis and Suncus murinus. Norway rats, $R$. norvegicus was the most trapped species in commercial areas whereas lesser bandicoot rats, $B$. bengalensis was the most captured species in residential areas.
\end{abstract}

Keywords: Small mammals, pest, urban, bait preference

\begin{abstract}
ABSTRAK
Tangkapan hidup adalah langkah pertama yang penting untuk mengawal populasi haiwan perosak dan identifikasi spesies serta pemilihan umpan adalah informasi penting untuk kawalan berkesan. Kajian ini dijalankan untuk mengenali kepelbagaian spesies dan pemilihan umpan oleh spesies commensal di kawasan urban di Pulau Pinang. Tangkapan dijalankan di lapan tapak kajian di Pulau Pinang melibatkan kawasan komersial dan kawasan perumahan. Lapan jenis umpan telah digunakan; epal dan mentega kacang (APB), roti dan mentega kacang (BPB), ikan masin (SF), ikan masin dengan mentega kacang (SFPB), roti dan ekstrak ikan (BFE), sisa ayam goreng (FCL), sayur dan mentega kacang (VPB) dan sosej (S). Umpan mendapat hasil tangkapan tertinggi adalah umpan dengan kandungan protein tinggi, iaitu umpan sisa ayam goreng (FCL) yang mencatatkan peratus tangkapan sebanyak $35.56 \%$. Kami turut membuat analisis pemilihan umpan berdasarkan spesies yang ditangkap sepanjang kajian. Lima spesies mammalia kecil yang ditangkap dalam kajian kami adalah Rattus norvegicus, Rattus rattus, Mus musculus, Bandicota bengalensis, dan Suncus murinus. Tikus Norway, $R$. norvegicus, adalah spesies yang paling banyak ditangkap di kawasan komersial manakala tikus Bandicoot, $B$. bengalensis merupakan spesies yang paling banyak ditangkap di kawasan perumahan.
\end{abstract}

Kata kunci: Mammalia kecil, perosak, bandar, pemilihan umpan 


\section{INTRODUCTION}

In Malaysia, there are nearly 200 sub-species from the genus Rattus that inhabit forests, islands and plantations (Lam et al., 1982). In the urban and agricultural field, 12 species have been identified and known as commensal rats (Paramasvaran et al., 2012). The most common commensal rats are Mus musculus, Rattus rattus and Rattus norvegicus (Parshad, 1999; Castillo et al., 2003). As commensal rats live in close proximity to human habitation, they share a variety of habitat ranging from the shore to mountain peaks, in towns, cultivated lands and forests (Paramasvaran et al., 2012). Different rat species tend to be selective in their habitats. However, agricultural and urbanization activities have led to changes of rat species diversity because their habitats are destroyed or disturbed (Walsh et al., 1993). Urbanization has also resulted in the accumulation of garbage, creating a favourable condition for rats (Behnke et al., 2001) which can adapt to any terrestrial habitat that can provide them with food sources. Commensal rats damage and contaminate food and non-food materials, whether in transit or storage. These damages lead to financial losses. More importantly, commensal rats are typically reservoirs of several communicable diseases.

Physical trapping is important as it is the first defence line of rat control to reduce the rat population. To ensure the success of a trapping, the most important step is to identify the species and to use the most preferred baits (e.g. Hice \& Velazco, 2013) as different rodent species prefer different types of bait (Khan, 1974; Yabe, 1979; Clapperton, 2006; Bealin \& Lawton, 2018). Therefore, this study was conducted to gather information on bait preference and species diversity of terrestrial pests in commercial and residential sites in urban areas of Penang Island.

\section{MATERIALS AND METHODS}

The study was carried out in Penang Island, Malaysia ( $\left.5^{\circ} 24^{\prime} \mathrm{N}, 100^{\circ} 14^{\prime} \mathrm{E}\right)$. Sampling sites were mainly at the east and south coast of Penang Island as these areas were the most populated and urbanized on the island. A total of eight sampling sites were selected within the island. Four sampling sites were located in the east, i.e. Georgetown, Jelutong, Gelugor and Bayan Baru, while another four sampling sites in the south and southwest of the island were at Teluk Kumbar, Bayan Lepas, Balik Pulau and Relau.

At each sampling site, baiting was carried out in selected commercial and residential areas. The commercial areas were mainly shop lots and wet markets. A total of 12 trapping areas were selected for commercial areas. The residential areas consisted of a cluster of houses, medium and low-cost flats with typically several small areas of vegetation. A total of six trapping areas were selected for this category. In general, sites with poor sanitation and inefficient waste management in selected areas were given the priority. The survey sites were chosen based on rat infestation signs, including presence of dropping, smear mark, burrow, nesting place and odour.

A total of 50 live traps were set up in each trapping area. Live traps of $27 \mathrm{~cm} \mathrm{x}$ $18 \mathrm{~cm} \times 13 \mathrm{~cm}$ dimension were used. The placement of the traps was along the trails of the rats, near the burrows and any other possible locations to maximize the number of captured rats. The traps were set at 1700 and collected at 0500 the following morning. 


\section{Bait preferences}

All traps were set up at the selected fields and baited with different foods or baits. Eight different types of baits were used: apple and peanut butter (APB), white bread and peanut butter (BPB), salted fish (SF), salted fish and peanut butter (SFPB), white bread and fish extract (BFE), fried chicken leftover (FCL), vegetables and peanut butter (VPB) and sausages (S). For the baits with peanut butter, a small piece of selected bait such as apple, white bread, salted fish, cucumber and sweet potato, were dipped into the peanut butter until fully covered. Meanwhile, for the white bread and fish extract bait, a quarter slice of white bread was soaked in the fish extract for about five minutes before being wrapped with a piece of mesh cloth. Fried chicken leftover bait was obtained from the leftover food of selected restaurants. All prepared baits were then hooked inside the trap. Three trap nights were done at each trapping area, with the eight different types of baits distributed throughout the period. Captured rats were identified, evaluated and recorded in the field.

\section{Rat species diversity}

The sampling sites included two different groups: commercial and residential areas. The traps were baited with the most favourable diet for rats: fried chicken leftover (FCL) and white bread and peanut butter (BPB). The traps were randomly placed either outdoor or indoor based on the building structure and sign of infestation. The sign of infestation were identified based on fresh dropping, smear mark, track, burrow and harbourage (Timm, 1994). Species identification of rats was based on morphological information with emphasis on fur structure, colour and length of body to tail ratio (Medway and Lim, 1966; Lim, 1970). Captured animals were then released, with the exception of captured Norway rats that were brought back to the laboratory for rodenticide residual analysis.

\section{Data analysis}

Trapping success percentage was calculated using the formula by Nelson and Clark (1973). All data were tested for normality prior to statistical analysis. A log transformation (ln) was applied to fulfil the assumption of chosen statistical analysis. One-way ANOVA test was used to determine the significance of bait preferences and number of commensal rats caught. Two - way ANOVA tests were used to examine the significance of the differences in species caught at different places. The statistical analysis was performed using the statistical package for social sciences (SPSS) for windows version 24.0.

\section{RESULTS}

\section{Bait preference of captured rats}

A total of 329 individual small mammals from five species were captured throughout the 54 trapping nights of the study. The five species captured were Norway rats, Rattus norvegicus, lesser bandicoot rats, Bandicota bengalensis, house shrews, Suncus murinus, roof rats, Rattus rattus and house mice, Mus musculus. The highest number of trapped rats was using fried chicken leftover (FCL) with a success percentage of $35.56 \%$ while the lowest trap success was using salted fish (SF) as bait (Fig. 1). 


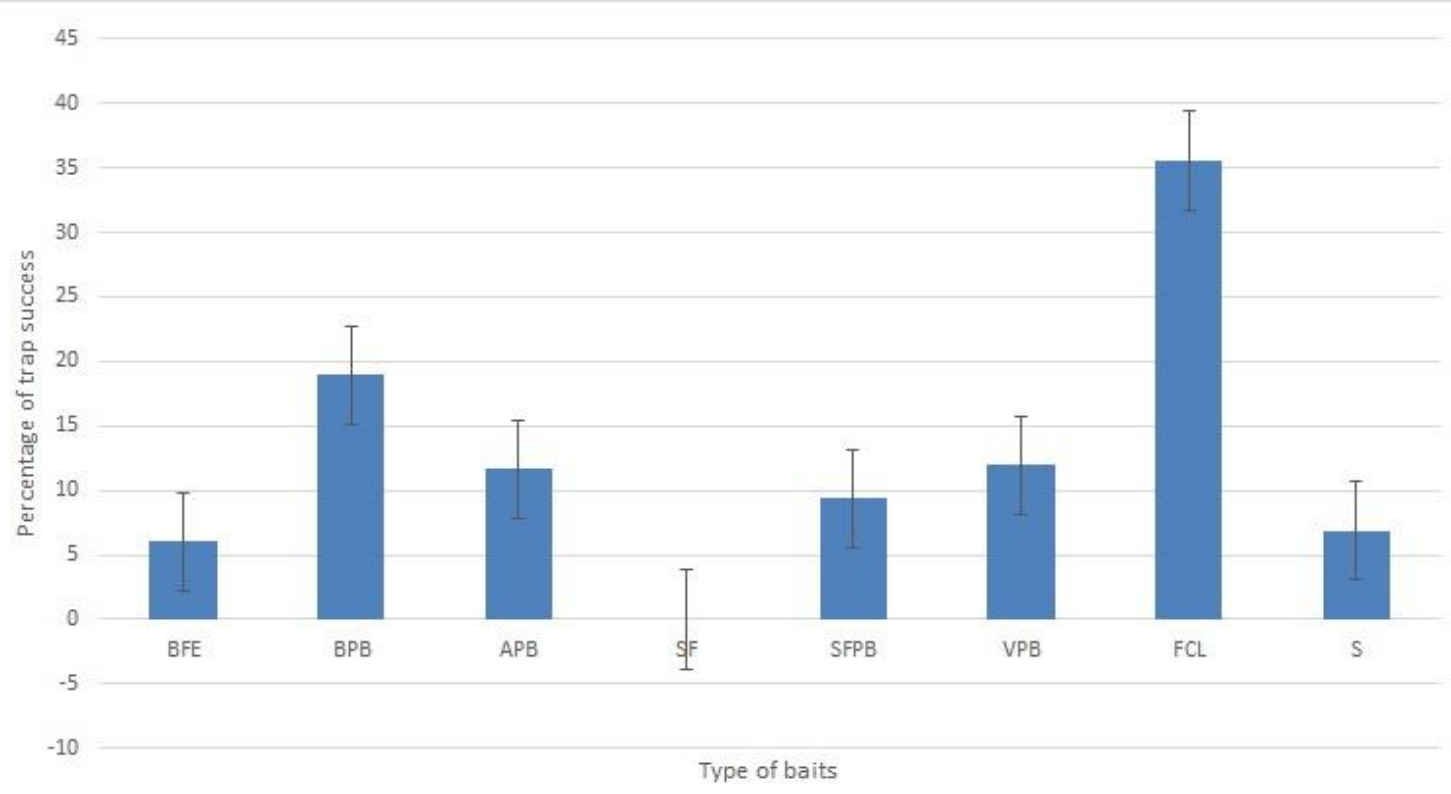

Figure 1. The percentage of trapped rats using different types of baits (numbers in column with different letter are statistically different by Tukey's test $(\mathrm{P}<0.05)$ after logarithmic transformation).

There was a statistically significant difference between the different types of baits as determined by one-way ANOVA $(F=4.024, \mathrm{df}=7, \mathrm{P}<0.05)$. Multiple mean comparison by Tukey's test revealed that the number of caught rats was statistically lower using S (1.667 \pm 0.333$)$, APB $(2.333 \pm 1.453)$, SFPB $(5.000 \pm 2.517)$, VPB $(5.333 \pm 0.333)$ and BPB $(8.667 \pm 1.856)$ compared to FCL $(12.667 \pm 4.667)$ as baits.

The mean number of rats caught using FCL was the highest at both commercial and residential areas, with $14.67( \pm 5.36)$ at commercial areas and 10.67 ( \pm 5.69$)$ at residential areas (Fig. 2). The mean number of rats caught using BPB in commercial areas was $8.30( \pm 1.45)$, which was higher than that in residential areas $(1.67 \pm 0.33)$ (Fig. 2). For VPB bait, the mean number of rats caught at commercial areas was $6.33( \pm 0.88)$ while in residential areas only $2.00( \pm 1.00)$ of rats were caught on average (Fig. 2). Using the APB bait, the mean number of rats caught at commercial areas was $2.00( \pm 1.00)$ while an average of $0.67( \pm 0.33)$ rats were caught in residential areas (Fig. 2). For the $\mathrm{S}$ bait, the mean number of rats caught at commercial areas was $0.67( \pm 0.33)$, which was lower in residential areas $(1.67 \pm 0.88)$ (Fig. 2). There was no capture using baits BFE, SF and SFPB at residential areas. However, at commercial areas the average number of rats captured was $1( \pm 0.58)$ using BFE and $4.67( \pm 2.02)$ using SFPB bait (Fig. 2).

There was no statistically significant difference between types of baits among commercial and residential sampling sites as determined by two-way ANOVA $(F=0.813, \mathrm{df}=7, \mathrm{P}>0.05)$. The Tukey's test revealed that the number of caught rats was statistically lower using $S$, APB, SFPB, VPB and BPB compared to FCL as baits. Moreover, the statistical analysis showed that there was a statistically significant difference between rat diversity caught in commercial and residential areas $(\mathrm{P}<0.05)$, but there was no significant difference between places and the number of commensal small mammal pests caught using different types of baits $(\mathrm{P}>0.05)$. 


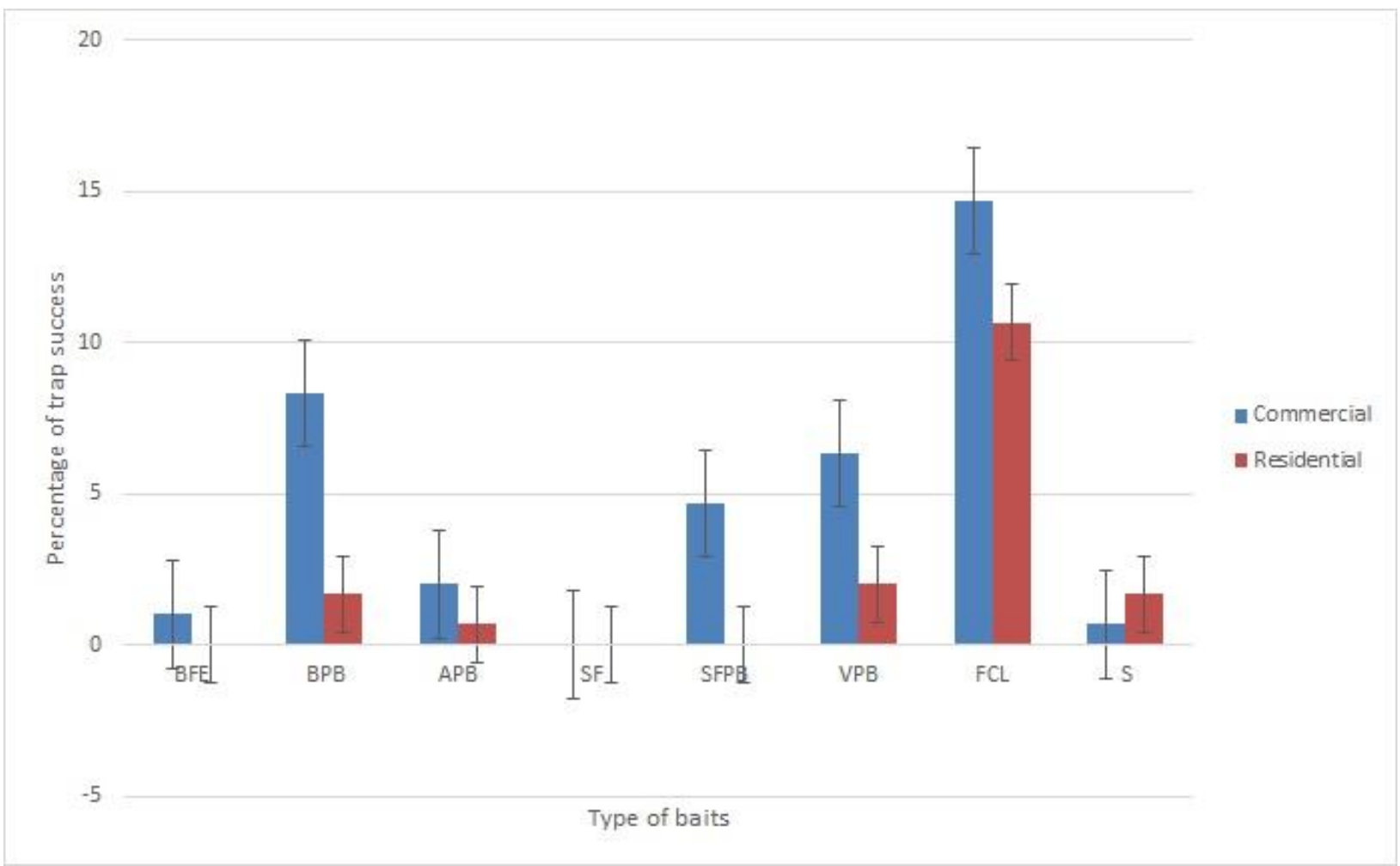

Figure 2. Mean number of rats trapped using different type of baits at commercial and residential areas (numbers in column with different letter are statistically different by Tukey's test $(\mathrm{P}<0.05)$ after logarithmic transformation).

\section{Bait preferences of individual captured} rodent species

Two species were caught using BFE bait: $B$. bangelensis and $R$. norvegicus (Table 1). There were four species caught using APB, SFPB and FCL as bait: $R$. norvegicus, $R$. rattus, $S$, murinus and $B$. bangelensis (Table 1). For BPB bait, there were three species of small mammals caught: $R$. norvegicus, $R$. rattus and $S$. murinus (Table 1). Four species were caught using SFPB, VPB and FCL: $B$. bengalensis, $R$. norvegicus, $R$. rattus and $S$. murinus (Table 1). There was no rat caught using SF as a bait. There was no statistical significant difference between species of rat caught and type of bait. 
Table 1. Number of individuals of each species captured using different type of baits

\begin{tabular}{|c|c|c|c|}
\hline Captured Species & Bait & Total individual captured & $\%$ of species captured \\
\hline \multirow{7}{*}{ Rattus norvegicus } & BFE & 6 & 5.83 \\
\hline & APB & 6 & 5.83 \\
\hline & BPB & 27 & 26.21 \\
\hline & FCL* & 45 & 43.69 \\
\hline & VPB & 18 & 17.48 \\
\hline & SFPB & 1 & 0.97 \\
\hline & Total & 103 & \\
\hline \multirow{6}{*}{$\begin{array}{l}\text { Bandicota } \\
\text { bengalensis }\end{array}$} & BFE & 3 & 3.85 \\
\hline & APB & 15 & 19.23 \\
\hline & FCL* & 42 & 53.85 \\
\hline & VPB & 16 & 20.51 \\
\hline & SFPB & 2 & 2.56 \\
\hline & Total & 78 & \\
\hline \multirow{7}{*}{ Rattus rattus } & $S$ & 15 & 13.64 \\
\hline & APB & 18 & 16.36 \\
\hline & $\mathrm{BPB} *$ & 36 & 32.73 \\
\hline & FCL & 2 & 1.82 \\
\hline & VPB & 18 & 16.36 \\
\hline & SFPB & 21 & 19.09 \\
\hline & Total & 110 & \\
\hline \multirow{7}{*}{ Suncus murinus } & $S$ & 2 & 5.56 \\
\hline & APB & 5 & 13.89 \\
\hline & BPB & 4 & 11.11 \\
\hline & FCL* & 14 & 38.89 \\
\hline & VPB & 5 & 13.89 \\
\hline & SFPB & 6 & 16.67 \\
\hline & Total & 36 & \\
\hline \multirow{2}{*}{ Mus musculus } & $\mathrm{APB} *$ & 2 & 100.0 \\
\hline & Total & 2 & \\
\hline
\end{tabular}




\section{Rat species and their diversity}

Following the success of the FCL and BPB baits, these two types of baits were applied at several selected residential and commercial sites around Penang Island. A total of 373 commensal pests were caught in this second stage of sampling. The dominant species at residential areas was $B$. bangelensis (19.20\%) and the dominant species at commercial areas was $R$. norvegicus (14.93\%) (Table 2). Overall, the dominant species of commensal rats in urban areas around Penang Island was $R$. norvegicus with $11.30 \%$ of trapping success. The percentage of trap success for
B. bengalensis was $7.51 \%, 4.69 \%$ for $S$. murinus, $2.07 \%$ for $R$. rattus and $0.14 \%$ for Mus musculus (Table 2).

A two-way ANOVA was conducted to analyse the species caught at different places. There was a statistically significant difference between places and the number of species caught $(F=6.996, \mathrm{P}<0.05)$. The statistical analysis also showed that the number of captures was significantly different with species $(\mathrm{P}<0.05)$, but there was no difference between sites and the number of commensal rats caught $(\mathrm{P}>$ $0.05)$.

Table 2. The percentage of different species of rats trapped at two different areas (Numbers in column with different letter are statistically different using Tukey's test $(\mathrm{P}<0.05)$ after logarithmic transformation).

\begin{tabular}{|c|c|c|c|}
\hline \multirow[b]{2}{*}{ Species } & \multicolumn{3}{|c|}{ Percentage of trapped rats $(\%)$} \\
\hline & Residential & Commercial & Total \\
\hline Rattus norvegicus & 4.40 & 14.93 & $11.30^{\mathrm{a}}$ \\
\hline Rattus rattus & 2.80 & 1.68 & $2.07^{\mathrm{b}}$ \\
\hline Mus musculus & 0.40 & - & $0.14^{\mathrm{b}}$ \\
\hline Bandicota bengalensis & 19.20 & 1.37 & $7.51^{\mathrm{b}}$ \\
\hline Suncus murinus & 6.40 & 3.79 & $4.69^{b}$ \\
\hline
\end{tabular}

\section{DISCUSSION}

\section{Bait preference}

Our results showed that high protein bait, i.e. fried chicken leftover (FCL) was the most attractive bait for commensal rats. In contrast to our results, rolled oats and peanut butter were often reported as the most attractive bait for small mammals (e.g. Clapperton, 2006; Diete et al., 2016). Rodents have shown an ability to differentiate baits based on nutritional cues and switched preferences through their experience (Partridge \& Maclean, 1981). It has been suggested that nutrition-deficient individuals will seek out a more varied diet for nutritional balance (Bealin \& Lawton, 2018). Since rodents are reported to elicit the strongest response to familiar substances (e.g., Bullard, 1985), the rats in commercial sites exposed to leftover food would be more familiar to the FCL bait.

Norway rats, lesser bandicoot rats and house shrews in this study preferred the 
FCL bait the most. Rattus norvegicus is known as an omnivorous eater but sometimes do have preferences in food (Yabe, 1979). Norway rats actively seek meat and fish (Harper \& Bunbury, 2015) and they are reported to prefer high protein, carbohydrate and fat content in baits (Brooks \& Bowerman, 1973; Nolte, 1999). Fruits and seeds were attractive to Norway rats (Yabe, 1979) and according to Khan (1974), among a variety of seeds, millet was the most preferred. Norway rats caught in dumping area and poultry sheds preferred sweet potatoes, peanuts, barley, sunflower seeds and corn (Brooks \& Bowerman, 1973). Experiments on food preference of wild Norway rats by Barnett and Spencer (1951) showed that liver was preferred over cereal baits. Norway rats also showed a preference for salty and sweet baits over bitter and sour baits (Barnett \& Spencer, 1951; Kolody et al. 1993). In Europe, Norway rats preferred fruits and cereals (Khan, 1974; Yabe, 1979) while in New Zealand, most of the species preferred oats and peanut butter (Clapperton 2006).

Paull et al. (2011) reported peanut butter with oats as the most attractive bait for two species of bandicoot, but in our study $B$. bengalensis showed a preference for the FCL bait, a high protein bait that was similarly preferred by commensal Norway rats. Shrews are opportunistic feeders (Grainger \& Fairley, 1978) who primarily feed on insects (Hamilton, 1940). Field et al (2017) who carried out a laboratory experiment of bait preference of $S$. murinus showed that shrews preferred crushed cockroaches over peanut butter rolled with oats although they also pointed out the logistical flaws in using crushed cockroaches as baits in the field. Our study showed that FCL, a high protein bait, was the most preferred bait type for house shrews, and was more logistically feasible than using crushed insects.

Unlike the other commensal species captured, roof rats captured in this study preferred the BPB bait over the FCL bait.
Roof rats are reported to mainly feed on fruits and seeds (Yabe, 1979) and prefer millet over other grains (Khan, 1974; Shahwar et al., 2015) although Harrison and Woodville (1950) have reported a preference for boiled rice. House mice in our study preferred the APB bait, which was fruit with peanut butter. However, it should be noted that we only had a small number of mice captured. A study on mice in Australia revealed that canary seeds, soft wheat and rice were the most preferred food as baits (Robards \& Saunders, 1988).

Trapping success was also affected by the availability of food in the surrounding field (Aplin et al., 2003). Commensal rats get a nutritionally balanced diet from a variety of available food around human settlement in urban areas; therefore, the baits used must be addictive and appealing towards commensal rats. A variety of additives and lure contents in baits have been studied by various researchers in order to attract more rats and increase the trap success. Baits containing sugar and butyric acid were the most attractive to commensal rat pests (Barnett, 1963; Clapperton, 2006) while some researchers have reported that poultry additives made bait more attractive to rodents (e.g. Singla \& Kanwar, 2014; Shahwar et al., 2015). According to Barnett (1963), baits must have complex flavours to attract commensal rats. Oils could increase bait acceptance and palatability (Meehan, 1984; Jackson et al., 2016), but the capture rates seemed to be limited by their odour (Schlötelburg et al., 2018). Barnett (1963) stated that most wild rats would sample everything within a range to avoid unfamiliar food which could contribute to bait avoidance. Rats such as $R$. norvegicus from areas with abundant food sources tended to be more neophobic (Priyambodo $\&$ Pelz, 2002). Therefore, the preferences of baits can vary based on the food source available in the field. 


\section{Species diversity at residential and commercial areas}

Two different aspects of urban areas were selected as study sites: residential and commercial areas. In residential areas, poor housing conditions and small patches of vegetation could provide refuge to small mammal pests (e.g. Langton et al., 2001) while in commercial areas, improper waste management would be a food source and hiding and nesting materials provide harbourage for commensal pests (Parshad, 1999). Five rat species were captured in this study. Norway rats, $R$. norvegicus was the dominant species in commercial areas and they are often associated with highly urbanized sites. These rats are often sighted in the drainage system and near garbage dumps with poor management. They also inhabit commercial areas such as markets, restaurants and shop lots that provide them with harbourage, food and water. Commonly found in cities, $R$. norvegicus is the most common rat that has spread widely in urban areas such as around central Baltimore (Gardner Santana et al., 2009), New York (Child et al., 1998) and some cities in England (Langton et al., 2001).

Certain species of commensal rats are able to outperform other rat populations and increasing urbanization elements also reduce the number of certain rat species (Cavia et al., 2009). Based on previous reports, the less important species infesting urban areas were lesser bandicoot rats and house shrews. However, based on the findings of this study, both of these species are becoming important. Bandicota bengalensis was the most captured small mammal pest species in heavily vegetated areas in the residential areas in this study. Residential areas provided suitable conditions for the construction of burrows compared to areas with high abundance of buildings. In India, B. bengalensis was the most predominant pest in agriculture sites and they had begun to invade urban areas such as Bombay, Delhi and Calcutta (Parshad, 1999). These commensal rats are confined to human settlements or to disturbing vegetation modified by man and are able to exploit and adapt to the urban environment as long as the environment provides food and nesting sites.

This study showed that the percentage of house shrew, S. murinus, caught in residential and commercial areas did not have significant difference. Lim (2015) reported that in Malaysia, house shrews commonly lived around housing areas. In Taiwan, house shrew was the commensal rat pests in traditional wet markets (Tung et al., 2013) but there were few reports of house shrew becoming urban pests, attacking buildings and contaminating food. However, house shrews have high prevalence of parasitic infections that are transmissible to human beings (Tung et al., 2013), making them potentially harmful commensal pests.

In our study, roof rats, $R$. rattus, were caught in both residential and commercial areas. Marsh (1994) stated that $R$. rattus were more abundant in high rise building areas that suit their climbing ability. Furthermore, the inside of buildings provides a suitable habitat for the species to build their nests. Roof rats were caught both outdoors and in the surrounding perimeter of buildings in this study, indicating that roof rats were adaptable in many areas whereas Norway rats were only found outdoors due to their large body size and restricted climbing capability. The least trapped species in this study was the house mouse, M. musculus, which was the least captured species in residential areas and no capture in commercial areas. Several other studies have also reported low numbers of mice trapped in urban areas (Vadell et al., 2010) and that the species were more abundant in vacant lots of small patches of vegetation surrounded by houses (Gómez et al., 2008; Vadell et al 2010). 


\section{CONCLUSION}

The most dominant species at commercial areas was Norway rats while the dominant species caught at residential areas in Penang Island was the lesser bandicoot rat. Overall, in terms of individual numbers caught, Norway rats were the most dominant species of small mammal commensal pest in Penang Island. Knowledge of bait preference is important to increase capture rate of a target species. In general, the most attractive bait for trapping outdoor rat species was a high protein bait, fried chicken leftover (FCL). While for indoor species, the most attractive bait was a combination of vegetables, bread and salted fish with peanut butter. This preference indicates that most commensal rats are attracted to high protein and high fat content baits.

\section{ACKNOWLEDGMENTS}

This work was funded by Felda Global Ventures (R\&D) Sdn. Bhd. through grant 304/PBIOLOGI/650760/F112 and Research University Grant 1001/PBIOLOGI/811270. We would also like to express our gratitude to the Barn Owl and Rodent Research Group (BORG) and School of Biological Sciences, Universiti Sains Malaysia for their support and assistance throughout the sampling.

\section{REFERENCES}

Aplin, K.A., Brown, P.R., Jacob, J., Krebs, C.J. and Singleton, G.R. (2003). Field methods for rodent studies in Asia and the Indo Pacific, Australian Centre for International Agricultural Research Monograph. pp. 26. Australia: Australian Centre for International Agricultural.

Barnett, S.A. (1963). The Rat: A Study in Behaviour. Chapter 3, Feeding Behaviour. Chicago, USA: Aldine Publishing Company.
Barnett, S.A., and Spencer, M.M. (1951). Feeding, social behaviour and interspecific competition in wild rats. Behaviour 3: 229-242.

Bealin, C., and Lawton, C. (2018). Bait preference in Irish small rodents. Irish Naturalists' Journal 36(1): 913.

Behnke, J.M., Bajer, A., Sinski, E. and Wakelin, D. (2001). Interactions involving intestinal nematodes of rodents: experimental and field studies. Parasitology 122: $39-49$.

Brooks, J.E. and Bowerman, A.M. (1973). Preference of wild Norway rats for grain, seeds and legumes. Pest Control 41: 13-39

Bullard, R.W. (1985). Isolation and characterization of natural products that attract or repel wild vertebrates. In: Acree, T., and Soderlund, D. (Eds.). Semiochemistry: Flavors and Pheromones. Walter de Gruyter \& Co., New York, pp. 65-93.

Castillo, E., Priotto, J., Ambrosio, A.M., Provensal, M.C., Pini, N., Morales, M.A., Steinmann, A., Polop, J.J. (2003). Commensal and wild rodents in an urban area of Argentina. International Biodeterioration \& Biodegradation 52: 135-141.

Cavia, R., Cueto, G.R. and Suarez, O.V. (2009). Changes in rodent communities according to the landscape structure in an urban ecosystem. Landscape and Urban Planning 90: 11-19

Child, J.E., Mclafferty, S.L., Sadek, R., Miller, G.L., Khan, A.S., Dupree, E.R., Advani, R. and Glass, G.E. (1998). Epidemiology of rodent bites and prediction of rat infestation in New York City. American Journal of Epidemiology 83: $590-598$ 
Clapperton, B.K. (2006). A review of the current knowledge of rodent behaviour in relation to control devices. Wellington, Science and Technical Pub., Department of Conservation.

Diete, R.L., Meek, P.D., Dixon, K.M., Dickman, C.R., and Leung, L.K.-P. (2016). Best bait for your buck: bait preference for camera trapping north Australian mammals. Australian Journal of Zoology 63: 376-382.

DOI: http://dx.doi.org/10.1071/ZO15050

Field, A.J., Copsey, J.A., Tragett, C.E.E., and Gode, M. (2017). Improving capture rate for an invasive species in Mauritius: determining Asian musk shrew Suncus murinus bait preference. Conservation Evidence 14: 16-19.

Gardner Santana, L.C., Norris, D.E., Fornadel, C.M., Hinson, E.R., Klein, S.L. and Glass, G.E. (2009). Commensal ecology, urban landscape, and their influence on the genetic characteristics of citydwelling Norway rats (Rattus norvegicus). Molecular Ecology 18(13): 2766-2778

Gómez, M.D., Priotto, J., Provensal, M.C., Steinmann, A., Castillo, E., and Polop, J.J. (2008). A population study of house mice (Mus musculus) inhabiting different habitats in an Argentine urban area. International Biodeterioration and Biodegradation 62:270-273.

Grainger, J.P., and Fairley, J.S. (1978). Studies on the biology of the pygmy shrew Sorex minutus in the west of Ireland. Journal of Zoology 186:109-141.

Hamilton, W.J. (1940). The biology of the smoky shrew (Sorex fumeus fumeus Miller). Zoologica 25:307-310.
Harper, G.A., and Bunbury, N. (2015). Invasive rats on tropical islands: their population biology and impacts on native species. Global Ecology and Conservation 3: 607627.

Harrison, J.L., and Woodville, H.C. (1950). Notes on the feeding habits of house-rats in Rangoon, Burma. Annals of Applied Biology 37: 296304.

Hice, C.L., and Velazco, P.M. (2013). Relative effectiveness of several bait and trap types for assessing small mammal communities in Neotropical rainforest. Occasional Papers, Museum of Texas Tech University 316: 1-15.

Jackson, M., Hartley, S., and Linklater, W. (2016). Better food-based baits and lures for invasive rats Rattus spp. and the brushtail possum Trichosurus vulpecula: a bioassay on wild, free-ranging animals. Journal of Pest Science 89: 479488. DOI: https://doi.org/10.1007/ s10340-015-0693-8.

Khan, J.A. (1974). Laboratory experiments on the food preferences of the black rat (Rattus rattus L.). Zoological Journal of Linnean Society 54: 167172.

Kolody, N., Brosvic, G.M., Pak, D., and Loeffler, S. (1993). Taste preference behavior in Long-Evans rats and Egyptian spiny mice. Bulletin of the Psychonomic Society 31: 307-310.

Lam, Y.M., Lee, A.K., Tan, Y.P. and Mohan, E. (1982). A Case Warfarin Resistance in Rattus rattus diardii. Mardi Research Bulletin 10(3): 378-383.

Langton, S., Cowan, D. and Meyer, A. (2001). The occurrence of commensal rodents in dwellings as revealed by the 1996 English House 
Condition Survey. Journal of Applied Ecology 38: 699-709

Lim, B.L. (1970). Distribution, relative abundance, food habits and parasite patterns of Giant rats (Rattus) in West Malaysia. Journal of Mammalogy 51(4): 730-740.

Lim, B.L. (2015). The house rodents and house shrew in Malaysia and Southeast Asia. UTAR Agriculture Science Journal 1(2): 45-50

Marsh, R.E. (1994). Roof rats. In: Hygnstorm S.E., Timm, R.M. \& Larson G.E. (eds.): Prevention and control of wildlife damage, pp. 125135, California, USA.

Medway, L. \& Lim, B.L. (1966). Fauna of Pulau Tioman: The specifics relations of Rattus tiomanicus. Bulletin of the National Museum Singapore 34: 33-38

Meehan, A.P. (1984). Rats and Mice: their biology and control. Sussex, UK: Rentokil.

Nelson, L. and Clark, F.W. (1973). Correction for sprung traps in catch/effort calculations of trapping results. Journal of Mammalogy 54(1): 295-298

Nolte, D.L. (1999). Impact of rodents on reforestation in the United States: problems and management. In: Zhibin, Z., Hinds, E., Singleton, G., and Zhang, Z. (Eds) Rodent biology and management. pp 84. In abstracts of papers presented at International Conference on Rodent Biology and Management, Beijing, China, 5-9 October 1998. ACIAR Technical Report 45.

Paramasvaran, S., Sani, $\quad$ R.A., Krishnasamy, M., Amal Nasir, M., Hassan, L., Mohd Zain, S.N., Jeffery, J., Santhana Raj, L., Latifa, I., Abdul Aziz, Vellayan, S. and Selvasan, S. (2012). An overview of nematodes infecting urban and wild rats (Muridae) in Malaysia. Malaysian Journal of Veterinary Research 3(1): 15-21

Parshad, V.R. (1999). Rodent control in India. Integrated Pest Management Reviews 4: 97-126

Partridge, L., and Maclean, R. (1981). Effects of nutrition and peripheral stimuli on preferences for familiar foods in the bank vole. Animal Behaviour 29: 217-220.

Paull, D.J., Claridge, A.W., and Barry, S.C. (2011). There's no accounting for taste: bait attractants and infrared digital cameras for detecting small to medium ground-dwelling mammals. Wildlife Research 38: 188-195. DOI:10.1071/WR10203

Priyambodo, S. and Pelz, H.J. (2002). Studies on neophobic behaviour in Norway rats (Rattus norvegicus) from farms in Germany. In: Singleton, G.R., Hinds, L.A., Krebs, C.J. and Spratt, D.M. (eds.): Rats, mice and people: Rodent biology and management. Bogor, Indonesia, pp.564, Australian Centre for International Agricultural Research.

Robards, G.E. and Saunders, G. (1998). Food preferences of house mice (Mus domesticus) and their implication for control strategies. Wildlife Research 25: 595-601.

Schlötelburg, A., Jakob, G., BellingrathKimura, S., and Jacob, J. (2018). Natural bait additives improve trapping success of common voles, Microtus arvalis. Applied Animal Behaviour Science 208: 75-81. DOI:

https://doi.org/10.1016/j.applanim. 2018.08.013

Shahwar, D., Hussain, I., Anwar, M., Beg, M.A., Kawan, A., and Akrim, F. (2015). Development of cereal baits 
and comparative field efficacy of some additives as bait carrier for zinc phosphide and coumatetralyl against rodent pests of poultry farms in Rawalpindi-Islamabad, Pakistan. International Biodeterioration and Biodegradation 104: 460-471.

Singla, N., and Kanwar, D. (2014). Poultry egg components as cereal bait additives for enhancing rodenticide based control success and trap index of house rat, Rattus rattus. Asian Pacific Journal of Tropical Biomedicine 4(Suppl 1): S341S347.DOI:10.12980/APJTB.4.201 $4 \mathrm{C} 1260$

Timm, R.M. (1994). Norway Rats. Prevention and Control of Wildlife Damage, 1994. Lincoln, USA: Institute of Agriculture and Natural Resources, University of Nebraska.
Tung, K.C., Hsiao, F.C., Wang, K.S., Yong, C.H. and Lai, C.H. (2013). Study of the endoparasitic fauna commensal rats and shrews caught in traditional wet markets in Taichung City, Taiwan. Journal of Microbiology, Immunology and Infection 46: 8588.

Vadell, M.V., Cavia, R., and Suárez, O.V. (2010). Abundance, age structure and reproductive patterns of Rattus norvegicus and Mus musculus in two areas of the city of Buenos Aires. International Journal of Pest Management 56(4): 327-336.

Walsh, J.F., Molyneux, D.H. and Birley, M.H. (1993). Deforestation effects on vector - borne diseases. Journal of Parasitology 106: 55-75.

Yabe, T. (1979). The relation of food habits to the ecological distributions of Norway rat (Rattus norvegicus) and the roof rat (Rattus rattus). Japanese Journal of Ecology 29: 235. 